\title{
Water Works Through Four Millenia in Turkey
}

\author{
Ünal Öziș ${ }^{1}$
}

Received: 16 April 2015 / Accepted: 4 July 2015 /Published online: 28 July 2015

(C) Springer International Publishing Switzerland 2015

\begin{abstract}
Turkey is one of the foremost open-air museums of the world with regard to historical water works from the last 4000 years. Some of them are still in operation after several centuries or even several millennia. There are remains of dams, irrigation canals, and water collection structures dating back to the $\mathrm{II}^{\text {nd }}$ millenium BC, the Hittite period in Central Anatolia. Several dams, irrigation canals, qanats date back to the first half of the $\mathrm{I}^{\mathrm{st}}$ millenium $\mathrm{BC}$, the Urartu period in Eastern Anatolia. Long-distance water conveyance systems, pipes, masonry canals, inverted siphons, tunnels, dams date back to the second half of the $\mathrm{I}^{\text {st }}$ millenium BC and the $\mathrm{I}^{\text {st }}$ millenium AD, the Hellenistic, Roman and Byzantine periods in Western and Southern Anatolia. Some dams, canals, watermills date back to the 11th to 14th centuries, the Seljukide period in Central and Eastern Anatolia. Several dams, irrigation canals, long distance water conveyance systems date back to the 14th to early 20th centuries, the Ottoman period in Turkey. Based on this tradition from four millenia, the modern Republic of Turkey, founded in 1923, is continuing to develop her water resources. The South-eastern Anatolia Project, encompassing the Euphrates-Tigris basin in Turkey, is the most interesting example.
\end{abstract}

Keywords Historical $\cdot$ Water work $\cdot$ Hydraulic $\cdot$ Structure $\cdot$ Turkey

\section{Introduction}

A very large number of ancient hydraulic works exist in Turkey (Fig. 1). Several ancient water works from this four-millenia-long period are still in operation after several centuries or even several millennia.

They date back to the IInd Millenium BC, the Hittite period in Central Anatolia; to the first half of the Ist Millenium BC, the Urartu period in Eastern Anatolia; to the second half of the Ist Millenium $\mathrm{BC}$ and the Ist Millenium AD, the Hellenistic, Roman and Byzantine periods in Western and Southern Anatolia; to 11th to 14th centuries, the Seljukide period in Central and Eastern Anatolia; to 14th to early 20th centuries, the Ottoman period in Turkey (Öziş 1994,

Ünal Öziș

yalcin.ozdemir@deu.edu.tr

1 Dokuz Eylül University, İzmir, Turkey 


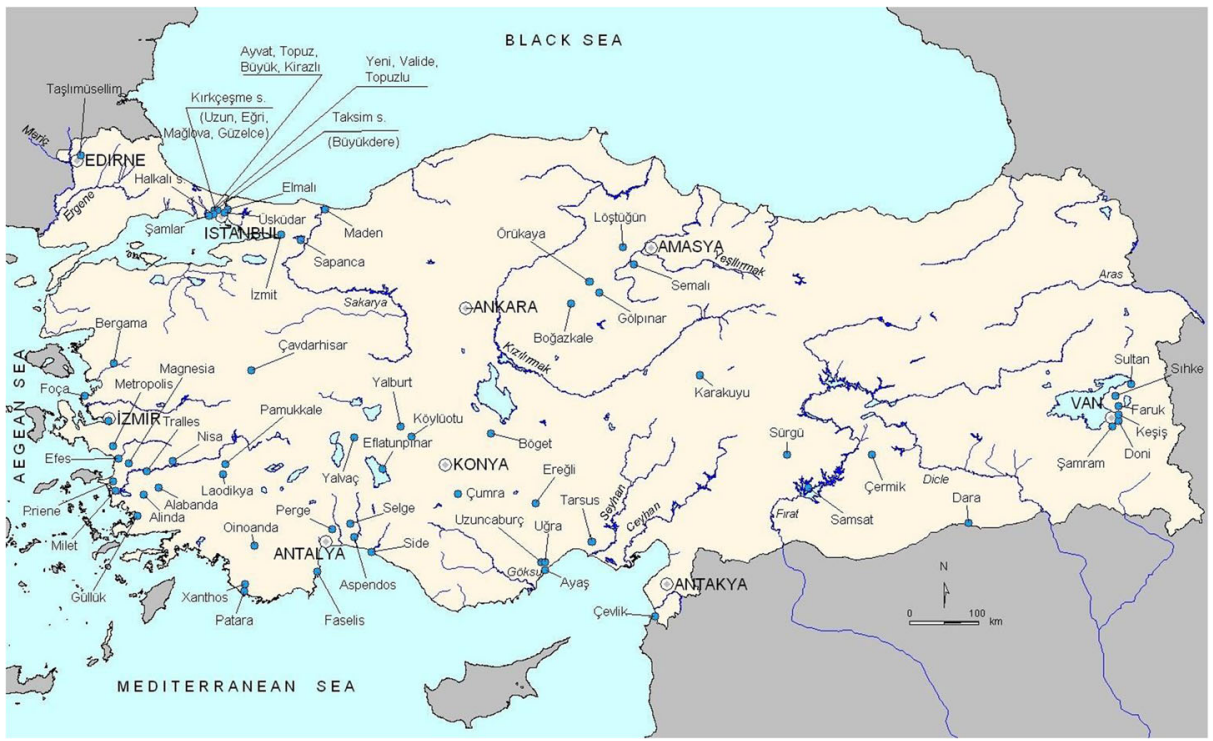

Fig. 1 Location of major historical water schemes in Turkey

1996, 1998, 1999, 2006; Bildirici 1994, 2004; D.S.İ. 2008; Öziș et al. 2009, 2014a; Unutmaz 2013).

These historical hydraulic works make Turkey one of the foremost open-air museums of the world in this respect. Some of them were given as interesting examples in relevant international books (Garbrecht 1985, 1987a, 1991a, 1995; Fahlbusch 1987a; Tölle-Kastenbein 1990; Hodge 1992; Grewe 1998, 2010; Viollet 2000; Crouch 2004; Wiplinger 2006a, 2013a, b, 2014; Nikolic 2008; Mays 2010; I.W.A. 2012); several of them were dealt with more detail in other international specific publications, as cited in subsequent sections.

\section{Hittite Water Works}

\subsection{Dams}

The most ancient hydraulic works in Turkey date back to the II $^{\text {nd }}$ Millenium BC, the Hittite period in Central Anatolia. Certain indices indicate that some wells and canals may even date back to the $\mathrm{VI}^{\text {th }}$ millenium $\mathrm{BC}$.

The $8 \mathrm{~m}$ high Karakuyu dam in Uzunyayla, with a total crest length of $400 \mathrm{~m}$, is a remarkable example. Eflatunpınar dam near Lake Beyșehir, Köylütolu and Yalburt dams near Ilgın, Güneykale dam near Boğazkale are other remains. The restituted Gölpınar dam near Alacahöyük is the most ancient dam actually in use (Emre 1993; Bildirici 1994, 2004; Öziş 1999; Çınaroğlu 2007; D.S.İ. 2008; İnal 2009; I.W.A. 2012; Strobel 2013).

\subsection{Water Supply}

The spring-water collection chamber in Boğazkale (Fig. 2), formed by rubble stones, has an almost triangular cross-section of about $1.4 \mathrm{~m}$ width and $2.6 \mathrm{~m}$ height (Neve 1969). 


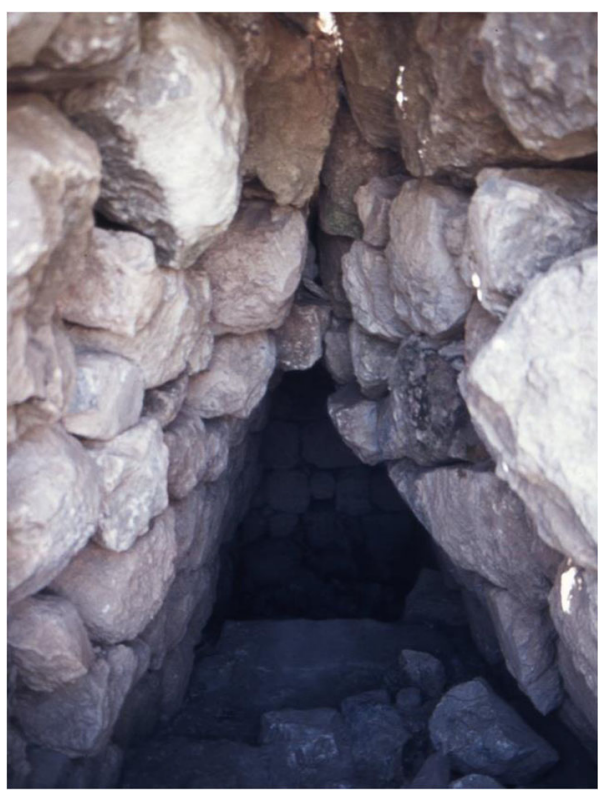

Fig. 2 Springwater collection chamber in Hattusha (photo:Ü.Öziş)

\subsection{Irrigation}

There are remains of several water conduits in ancient Hittite settlements and irrigation systems in Central Anatolia (Bildirici 1994, 2004; Bildirici and Bildirici 1996; D.S.İ. 2008).

\section{Urartu Water Works}

\subsection{Dams}

There are several small dams from the first half of the $\mathrm{I}^{\text {st }}$ Millenium BC, the Urartu period in Eastern Anatolia. These are located mostly on various watercourses flowing to Lake Van.

Some of them, like the $7 \mathrm{~m}$ high dam raising the level of the Lake Keşiş, those on Doni creek, are still in use. Kırcagöl dam near Adilcevaz, Süphan and Argit dams near Muradiye, several small dams between Van and Hakkari are other remains (Garbrecht 1987a; Belli 1996; Öziș 1999; Bildirici 2004; D.S.İ. 2008).

\subsection{Water Supply and Irrigation}

The $56 \mathrm{~km}$ long Şamram canal (Fig. 3) supplied the Urartu capital Tushpa (Vankale). This canal dates back to $800 \mathrm{BC}$ and is one of the oldest canals still in use. The Şamram canal irrigates, with very few modifications, about 2000 ha of land (Ögün 1970; Burney 1972; Garbrecht 1975; Belli 1997).

Remains of the Ferhat canal, conveying water from Lake Balıklı towards the western edge of the Iğdır plain, some other irrigation systems in Van area, might also date back to the Urartu period. 


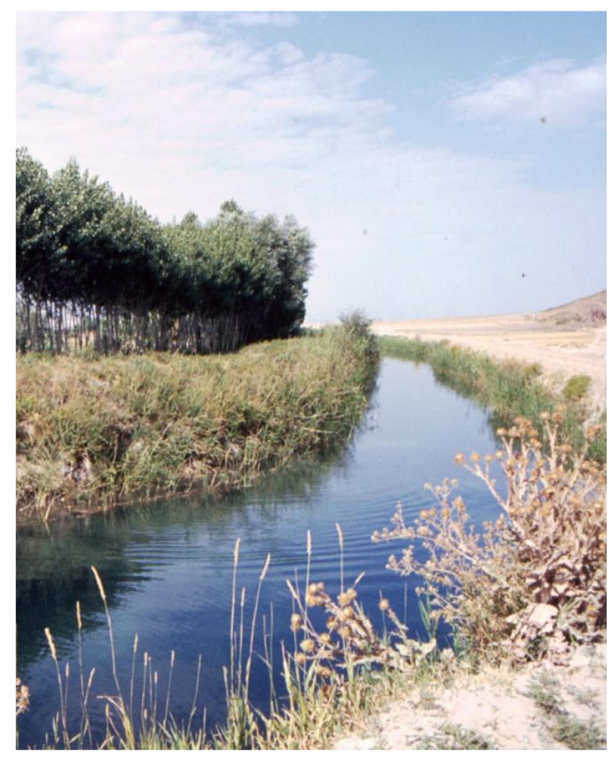

Fig. 3 Şamram canal near the Urartu capital Tushpa (Van) (photo:Ü.Öziş)

Some of the underground water conduits of Van, still partly in use, might also date back to this period and can be considered as predecessors of later qanats. Certain cisterns in this region appear to be of Urartu origin (Bildirici 2004; D.S.İ. 2008).

\section{Hellenistic, Roman and Byzantine Water Works}

\subsection{Water Supply and Conveyance Schemes}

Hellenistic, Roman and Byzantine long-distance water supply schemes in Western and Southern Turkey date back to the second half of the $\mathrm{I}^{\text {st }}$ Millenium BC and the first half of the $\mathrm{I}^{\text {st }}$ Millenium AD. Those from the roman and early byzantine periods are of special importance.

The long-distance water conveyances in the Aegean and Mediterranean regions of Turkey are very numerous and new discoveries add to the rich variety of them (Fahlbusch 1987a; Büyükyıldırım 1994; Öziş 1996; Wiplinger 2006a, 2013a, b; Tanrı̈ver et al. 2006; D.S.İ. 2008; Türk et al. 2010).

These systems include spring-water collection chambers; lead-, stone-, clay-pipes of various sizes; rock-cut and masonry canals; tunnels of over $2 \mathrm{~m}$ height; inverted siphons under up to $190 \mathrm{~m}$ pressure with lead-, to $155 \mathrm{~m}$ pressure with stone-pipes; aqueducts of up to $40 \mathrm{~m}$ height.

The $242 \mathrm{~km}$ long water conveyance system along the south-western slopes of the Istranca mountains in Thrace to İstanbul, constructed for the new capital of the late Roman Empire in 4th century AD, was by far the longest water conveyance system of ancient times (Çeçen 1996). Two aqueducts of this system, Mazul and the almost $1 \mathrm{~km}$ long Valens (Bozdoğan) (Fig. 4) aqueducts, were later used by several ottoman water conveyance systems, among others the Süleymaniye water conveyance by the great Sinan in 16th century. 


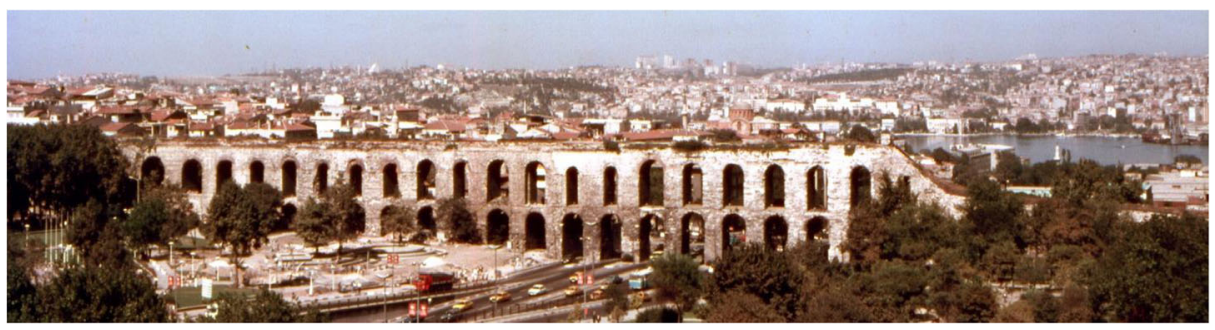

Fig. 4 Valens (Bozdoğan) aqueduct in the East Roman / Byzantine capital Constantinople (İstanbul) (photo:Ü.Öziș)

The water conveyance to Phoceia (Foça) with $100 \mathrm{~km}$ length ranks among the longest roman conveyance systems (Öziş 1996; D.S.İ. 2008).

The multiple water conveyance systems to Pergamon (Bergama) (Fahlbusch 1987b; Garbrecht 1987b), to Smyrna (İzmir) (Weber 1899; Öziș et al. 1999; D.S.İ. 2008), to Ephesus (Efes) (Öziș et al. 1998, 2005, 2014b; Öziș and Atalay 1999; Wiplinger 2006a, 2010, 2013a, b; Acatay 2008; D.S.İ. 2008; I.W.A. 2012; Kreiner 2013) make these cities, besides Rome, Lyon and few others, among the most interesting examples of multiple urban water supply schemes in the antique world. The respectively longest systems display lengths of $65 \mathrm{~km}$ at Pergamon, $30 \mathrm{~km}$ at Smyrna, $42 \mathrm{~km}$ at Ephesus.

The water conveyance systems to Perge (Büyükyıldırım 1994), Hierapolis (D.S.İ. 2008), Tralleis (Baykan and Tanriöver 2006) are other, somewhat shorter multiple water conveyance systems in Anatolia.

The lead-pipe inverted siphon of the Madradağ water conveyance to Pergamon resists up to $190 \mathrm{~m}$ water pressure, the $3.3 \mathrm{~km}$ long stone-pipe inverted siphon of the Karapınar water conveyance to Smyrna resists up to $155 \mathrm{~m}$ water pressure. These were siphons operating under respective largest pressures in the antique world, dating back to the late centuries of the 1st millenium BC Hellenistic period. The stone-pipe inverted siphon of Aspendos is, with about $1.7 \mathrm{~km}$ length, the longest on arches in Turkey (Alkan et al. 2014).

The ruined aqueduct over Karkassos (Ilyas) creek of the Soma conveyance to Pergamon, would have had a height of $40 \mathrm{~m}$, being the second highest roman aqueduct after Pont-du-Gard of Nîmes.

Among the other water conveyance systems of interest are those of $40 \mathrm{~km}$ to Samosata (İzmirligil 1983); of Lamas-basin (36 km to Diocaeserea; $25 \mathrm{~km}$ to Elaiussa Sebaste and Korykos, $20 \mathrm{~km}$ to Olba) (Arısoy et al. 1987; Öziş 1996; D.S.İ. 2008; Murphy 2013); of $25 \mathrm{~km}$ to Side (İzmirligil 1979; Büyükyıldırım 1994; Grewe 1994); of 24 km to Amaseia (D.S.İ. 2008); of $22 \mathrm{~km}$ to Alabanda (Öziș et al. 1979a; Öziș 1991; D.S.İ. 2008); of $22 \mathrm{~km}$ to Magnesia (Baykan et al. 2001; D.S.I. 2008); of $22 \mathrm{~km}$ to Tripolis (D.S.I. 2008); of $21 \mathrm{~km}$ to Metropolis (D.S.I. 2008); of $21 \mathrm{~km}$ to Patara (Baykan et al. 1997; Baykan and İșkan 2011; İșkan and Baykan 2013); of $17 \mathrm{~km}$ to Aspendos (Fahlbusch 1987c; Kessener and Piras 1997; Kessener 2001; Ortloff and Kassinos 2003); of $17 \mathrm{~km}$ to Sardes (D.S.I. 2008); of $12 \mathrm{~km}$ to Alinda (D.S.İ. 2008).

Some shorter water conveyances attracted also international interest; such as Laodicea (Baykan 1999; Büyükkolanc1 and Şimșek 2006; D.S.İ. 2008; Alkan et al. 2014); Perge (Fahlbusch 1987d; Büyükyıldırım 1994); Aphrodisias (Commito and Rojas 2010); Antiochia/Orontes (Döring 2012);

Oenoanda (Stenton and Coulton 1986; Coulton 1987; Baykan and Cantilav 1997; Alkan et al. 2014); Iassos (Tomasello 1991); Xanthos (Büyükyıldırım 1994; Burdy and Lebouteiller 
1998); Antiochia/Psidia (Burdy and Tașlıalan 1997); Keramos (Bildirici 2006; D.S.İ. 2008); Ilion (Kayan 2000; Aylward et al. 2002; Aylward 2006); Ariassos (Owens 2006); Rhodiapolis (Murphy 2006); Sagalassos (Martens 2006); Sbede (Bildirici 2014).

Furthermore, some water conveyances in Turkey's mediterranean region, like Phaselis, Selge, and in Western Anatolia, like Aigai, Sebastopolis, Pınara, Attuda, Trapezopolis, Nysa, Knidos, Arykanda, Eumenia, Mylasa (with an apparently $2.3 \mathrm{~km}$ long, damaged aqueduct) were investigated at national context (Büyükyıldırım 1994; D.S.İ. 2008).

Water distribution and wastewater collection systems of certain hellenistic-roman-byzantine cities in Anatolia deserve also special attention, such as Priene, Miletus, Ephesus, Hierapolis, İstanbul (Bildirici 2002; Crouch 2004; Ortloff and Crouch 1998, 2001; Wiplinger 2006b; Tuttahs 1998; I.W.A. 2012; Strobel 2013; Uytterhoeven 2013).

Covered and open cisterns in İstanbul, dating back to 4th to 6th centuries $\mathrm{AD}$, are extraordinary examples of antique cisterns. They were the largest of their kinds, with side lengths up to $150-250 \mathrm{~m}$. Noteworthy are the covered cisterns Yerebatan with 336, Binbirdirek with 234 columns (Eyice 1979; Öziș 1982; I.W.A. 2012).

There are also other sites with important cisterns, like Termessos (I.W.A. 2012), Rhodiapolis (Murphy 2006); Sagalassos (Martens 2006).

\subsection{Structures Covering Water Courses}

The tunnel-like twin structures from the Roman period, covering the Bergama creek, date back to early 2 nd century AD; they were the largest of their kind with $7.5 \mathrm{~m}$ height and $9 \mathrm{~m}$ width each; they have a capacity of $720 \mathrm{~m}^{3} / \mathrm{s}$ and are still in situ.

There exist also two less large structures, the one in Nysa with dimensions close to $6 \mathrm{~m}$ and a capacity of $290 \mathrm{~m}^{3} / \mathrm{s}$, that in Acarlar near Ephesus with dimensions of 3.3-4.9 m and a capacity of $70 \mathrm{~m}^{3} / \mathrm{s}$ (Öziş et al. 1979b, 2010; Grewe et al. 1994; D.S.İ. 2008; Baykan et al. 2011).

\subsection{Tunnels}

The tunnel and river diversion system at Çevlik dates back to the Roman period. The construction began in 1 st and ended in 2 nd century AD. It was aimed to prevent the silting of the harbor of Seleucia Pieria near Antakya.

The $875 \mathrm{~m}$ long system has a capacity of $70 \mathrm{~m}^{3} / \mathrm{s}$. It encompasses two tunnel stretches of 90 and $30 \mathrm{~m}$ in length. The cross sections are of simple horseshoe or trapezoidal, with dimensions in the order of 6-7 m; and was the largest of its time (Alkan and Öziș 1991, 2013; Garbrecht 1991b; Grewe 1998, 2010; D.S.İ. 2008; Grewe et al. 2010; Öziş et al. 2010; Baykan et al. 2011).

The $250 \mathrm{~m}$ long Bezirgan tunnel near Kalkan, with $1.1 \mathrm{~m}$ width and $2.2 \mathrm{~m}$ height, serves as flood water emissary of the karst polje (Genç et al. 2010; Öziş et al. 2010; Baykan et al. 2011).

There are some water channels, dating back to 4th-3rd centuries BC, at the Amasya castle, located on the mountain overlooking the city (D.S.I. 2008).

\subsection{Dams}

Several dams in Central Anatolia, dating back to the early centuries of the $\mathrm{I}^{\text {st }}$ millenium AD, like the $16 \mathrm{~m}$ high Örükaya, $16 \mathrm{~m}$ high Çevlik, $10 \mathrm{~m}$ high Çavdarhisar, $4 \mathrm{~m}$ high Böget, others 
dating back to the 6th century AD, like the Dara dams near Mardin in South-eastern Anatolia, are interesting remains from this period. The Ildır dam near Çeşme, the Löştüğün dam near Amasya date probably back to the second half of the $\mathrm{I}^{\text {st }}$ millenium AD. Sultan and Sihke dams near Van, with some Urartu origins, might also date from the same period (Schnitter 1979; Garbrecht 1991c; Öziş 1999).

\subsection{Water Power}

There are numerous remains of water mills in Turkey; it is hard to conclude that some of them date back to this period. It is believed, however, that the first water wheel has been constructed in 4th century BC in Cabeira (Niksar) in Turkey (I.W.A. 2012).

Remains of roman water-powered stone saws were found at some locations in Anatolia (Seigne and Morin 2006; Grewe and Kessener 2007).

\section{Seljukide Water Works}

\subsection{Dams}

Certain dams in Turkey date back to 11th to 14th centuries, the Seljukide period in Central and Eastern Anatolia. The remains of some dams have been submerged in the reservoirs of modern dams like Altınapa and Sille, others damaged by outside effects.

The most interesting example is probably the $12 \mathrm{~m}$ high Faruk dam near Van, with a crest length of $30 \mathrm{~m}$, before the left half collapsed in 1988. The estimates for the construction date of the Faruk dam varies from the Urartu to Ottoman periods, but the appropriate dating appears to be Seljukide (Schnitter 1979; Çeçen 1987; Garbrecht 1991d; Öziș 1999; Bildirici 2004; Öziş et al. 2007).

\subsection{Irrigation}

The Sahip Ata irrigation canals in Konya date back to the 13th century. The irrigation systems in Ereğli and at other places in Central Anatolia, some of them with probable Hittite origins, date also back to the Seljukide period; a few of them are still in operation (Bildirici and Bildirici 1996; Bildirici 2004). Some underground conduit systems might date back to this period (I.W.A. 2012).

\subsection{Water Power}

The supply canal of a water-mill at Çermik passes through an asymmetrical opening of the Seljukide Haburman masonry bridge from 12th century (Fig. 5). This is apparently one of the most ancient water power schemes in Anatolia, being still in operation (Öziş et al. 2007).

\subsection{Hydromechanics}

The book by Ebul-feyz El Cezeri, who was named after the town Cizre in South-eastern Anatolia, is a 12th century masterwork on ingenuous hydro-mechanical devices (Cezeri 1196; Hill 1974; Çeçen 1979a; I.W.A. 2012). 


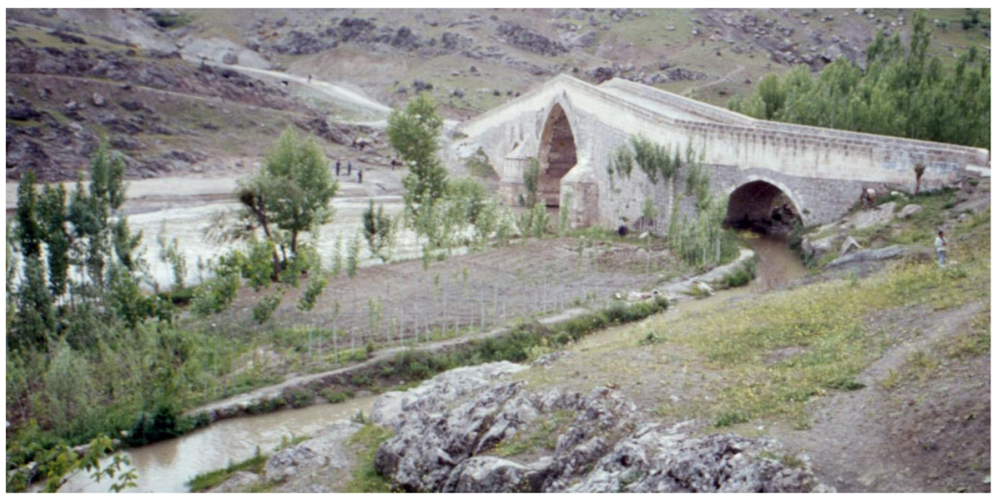

Fig. 5 Watermill supply canal through the Seljukide Haburman bridge in Çermik (photo:Ü.Öziş)

\section{Ottoman Water Works}

\subsection{Water Supply and Conveyance Schemes}

The Halkalı water conveyance systems to İstanbul were constructed in the period of 1450's to 1750 's. They consist of 16 systems with a total length of $130 \mathrm{~km}$, including the $50 \mathrm{~km}$ long Süleymaniye water conveyance by the great engineer and architect Sinan in 1550's. The conduits are basically baked clay pipes, with certain tunnel sections and passing over some aqueducts; the Süleymaniye system made even use of the 4th century Mazul and Bozdoğan aqueducts (Çeçen 1979b, 1988, 1990, 1991a; Öziş 1984, 2001; Öziş and Arısoy 1987, 1996, 2000, 2003; Öziş et al. 2007; Acar 2010; I.W.A. 2012).

The $50 \mathrm{~km}$ long Taşlımüsellim water conveyance system to Edirne, is also considered as a work of Sinan, dating back to 1530's and expanded some decades later. The conduit is a masonry gallery; the alignment passes over several aqueducts and includes certain tunnel sections; the system is for the large part still in operation (Öziş and Arısoy 1986, 1987, 1988, 1996, 2000, 2003; Öziş et al. 2007; D.S.İ. 2008).

The $55 \mathrm{~km}$ long Kurkçeșme water conveyance system to İstanbul from 1560's, is one of the masterworks of Sinan, with four major aqueducts (Uzun, Eğri, Mağlova, Güzelce). The system includes more than thirty aqueducts of various sizes. The conduit is a masonry gallery, and is for the large part still in operation (Çeçen 1979b, 1988, 1990; Öziş 1984, 1987, 2001; Schnitter 1990; Öziş and Arısoy 1987, 1996, 2000, 2003; Öziş et al. 2007; D.S.İ. 2008; I.W.A. 2012).

Sinan's schemes are the most important long-distance water conveyance systems since Roman times. The aqueducts Uzun, Eğri, Mağlova (Fig. 6), Güzelce of the Kırkçeșme system, with heights up to $35 \mathrm{~m}$ and lengths up to $700 \mathrm{~m}$, rank among the largest of their kinds in all times.

The Üsküdar water conveyance systems, to the east of Bosphorus in İstanbul, date back to 16th to 19th centuries. The conduits are mostly baked clay pipes; noteworthy are the water balance towers for pressure control and distribution (Çeçen 1979b, 1991b; Öziş et al. 2007; Dinçkal 2001; I.W.A. 2012).

The $23 \mathrm{~km}$ long Taksim water conveyance to İstanbul dates back to 1730's, and is still for the large part in operation. The conduit is a masonry gallery; it includes a $400 \mathrm{~m}$ long aqueduct and initially an interesting inverted siphon. Collecting water from the same area, a new system 


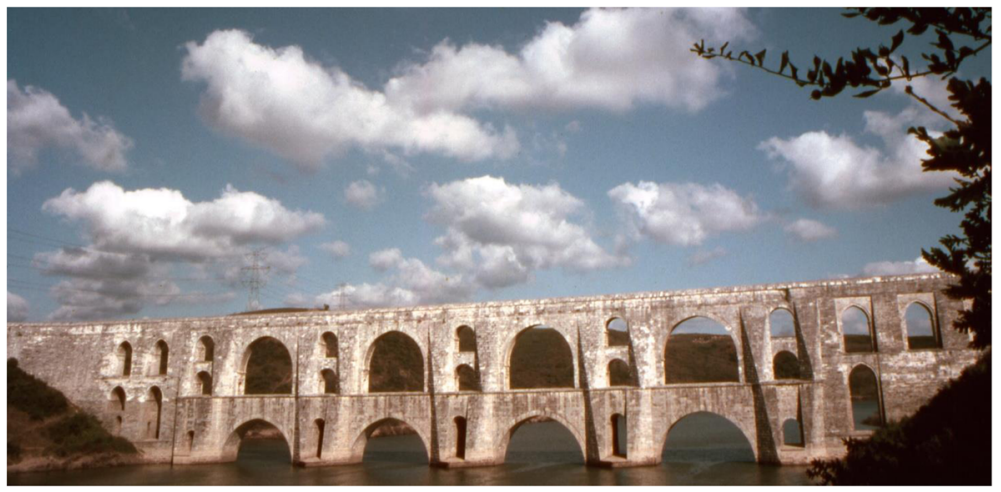

Fig. 6 Mağlova aqueduct on the Kırkçeșme water conveyance system to the Ottoman capital İstanbul (photo: Ü.Öziş)

for drinking water purpose, the Hamidiye water conveyance, has been constructed in the 19th century (Çeçen 1979b, 1992; Öziș 2001; Öziș et al. 2007; I.W.A. 2012).

The short Kilyos water conveyance near İstanbul, is interesting with regard to the water balance towers (Bildirici 2008).

The diversion and conveyance of Ephesus' Değirmendere waters to Kuşadası, the water conveyance with aqueducts to Foça date back to ottoman times; some of the ottoman water conveyances to İzmir (Öziş et al. 1999; D.S.İ. 2008), the Paşasuyu water conveyance to İzmit (Ünal 2001) have roots in ancient periods.

The water supply systems of Şanlıurfa, having roots in the Seljukide period (Gerger and Kürkçüoğlu 1997; I.W.A. 2012); of Bursa (I.W.A. 2012), of Çorum (I.W.A. 2012), of Safranbolu (I.W.A. 2012) are other interesting systems.

Besides the water conveyances, the water distribution and wastewater collection systems of İstanbul deserve also special interest (Sarıkaya et al. 2001; Bildirici 2002; Dinçkal 2005; I.W.A. 2012).

The cisterns, especially in western and southern regions of Turkey, are quite interesting (I.W.A. 2012).

\subsection{Dams}

In the period of 1620 to 1839 , the Kırkçeșme system is supplemented by four (Topuz, Büyük, Ayvat, Kirazlı), the Taksim system by three (Topuzlu, Valide, Yeni) dams, with heights up to $17 \mathrm{~m}$ and crest lengths up to $104 \mathrm{~m}$. All these dams, located at the Belgrad Forest to the north of İstanbul, are still in operation (Öziş 1977, 1981, 1984, 1999; Çeçen 1979b, 1987, 1988, 1990; Schnitter 1994; Öziş et al. 2007; D.S.İ. 2008; Acar 2010).

The majority of dams constructed until these centuries were embankment dams, and masonry dams were rarely encountered; thus, the masonry dams of İstanbul deserve a special place with regard to the historical development of dams.

There are also some later dams of 19th century like Șamlar and Elmalı I dams around İstanbul (Çeçen 1987; Öziş 1999), the 23 m high Maden dam near Karasu. The Semalı embankment dam near Amasya, mentioned in certain sources that the imperviousness was achieved by covering the upstream face with ox-skins, is considered as an Ottoman dam (Öziș 1999). 


\subsection{River Diversion}

The engineer and architect Sinan planned in 1583 the diversion of the Sakarya River to the Marmara Sea over the Lake Sapanca, for flood control, water power (mills), river navigation purposes. This idea had roots in 16th century, but could not be yet realized until present times (Çeçen 1981).

The Gediz River was diverted to the outer bay in late 19th century, in order to prevent the closure of the İzmir Bay (Öziș 1994).

\subsection{Irrigation}

Various irrigation systems under actual operation have their roots in ottoman times, like the Sürgü irrigation near Malatya from 19th century, the Beyșehir-Çumra irrigation south of Konya from early 20th century (Öziş 1994; Öziş et al. 2009).

\subsection{Water Power}

The first electricity was generated in Turkey in 1902 at the Tarsus hydroelectric scheme, at the dawn of the Ottoman Empire (Öziş 1994; Öziş et al. 2009, 2014b). The scheme used the elevation difference of the Berdan River at Tarsus falls.

\section{Conclusion}

Ancient hydraulic works, dating from all periods of her last 4000 year long history, make Turkey one of the foremost open-air museums in this respect. Some of them are, with very few repairs or modification, still in operation after several centuries, even millenia.

Based on this tradition, Turkey continues to harness her water resources, including very important schemes like the Southeastern Anatolia Project, the Karakaya and Atatürk dams and power plants, the twin Şanliurfa tunnels. Turkey anticipates the development of the bulk of her water resources until 2023, the centennial of the foundation of the modern Republic of Turkey.

Acknowledgments The author gratefully acknowledge the support of the Ege and Dokuz Eylül Universities in the office work; as well as various institutions in the field investigations, such as D.S.I. (State Hydraulic Works Authority), İ.S.K.I. (Water and Sewerage Authority of Istanbul), the Municipality of Edirne, Turkish Armed Forces, Rural Services Authority, Mediterranean Irrigation Union, T.G.T. Power Stations Company, SU-YAPI Engineering and Consulting Company, ATA Construction Company, Austrian Archeological Institute, Ephesus Museum, Antakya Museum, Museum of Turkish and Islamic Art, Topkapı Palace Museum, Süleymaniye Library.

For the encouragement showed to his work, the author wish to extend his gratitude to the late Ord.Prof.Dr. Ekrem Akurgal and to many personalities in the fields of archeology and history, as well as to the late Prof.Dr. Kazım Çeçen and to many personalities in the field of civil engineering, from Turkey and abroad.

Furthermore, the author wishes to thank his close colleague civil engineers for their contributions, many of them being also his former students, whose names often appearing as co-authors of publications cited in the lists of references.

In this context, the present text is based on the special manuscript prepared for DSI at the 5th World Water Forum (Öziș et al. 2009); on the paper presented at the 3rd IWA Specialized Conference on Water and Wastewater Technologies in Ancient Civilizations (I.W.A. 2012), on the recent article published in the journal Wasserwirtschaft (Öziș et al. 2014).

The author thanks the organizers of the EWRA 2015 9th. World Congress in İstanbul for inviting him to present this key paper.

Last but not the least; the author thanks the Frontinus-Gesellschaft e.V. (Berlin) for awarding him the Frontinus-Medal in 2014, with regard to his scientific work on the historical hydraulic structures in Turkey. 


\section{References}

Acar Ş (2010) Bentler ve Sinan'ın suyolu. Biryıl, İstanbul

Acatay T (2008) Efes'in tarihi suyolları. In: Tarihi su yapıları konferansı, Devlet Su İșleri, İzmir, pp 189-193

Alkan A, Öziş Ü (1991) Çevlik canal and tunnels from the point of view of hydraulics engineering history. In: Digest 91, Chamber of Civil Engineers, Ankara, pp 92-95

Alkan A, Öziş Ü (2013) Ancient tunnel and diversion channel in Seleuceia Pieria - a flood diversion system near Antiochia in Turkey. J Civil Eng Urban 1:1-5

Alkan A, Özdemir Y, Baykan O (2014) Inverted siphons in Western Anatolia. Frontinus-Gesellschaft-Hefter 28: $55-70$

Arısoy Y, Öziş Ü, Kaya B (1987) Lamas havzası tarihi su getirme sistemleri. In: IX. Teknik Kongre, İnşaat Mühendisleri Odası, Ankara, 2/363-376

Aylward W (2006) The aqueduct of Ilion (Troy) and the supply of the city's nymphaeum and bath. In: Wiplinger G (ed) Cura Aquarum in Ephesus 2004. Österreichisches Archäologisches Institut, Wien, pp 107-115

Aylward W, Bieg G, Kayan I (2002) The aqueduct of roman Ilion and the bridge across the Kemerdere valley in the Troad. Stud Troica 12:397-427

Baykan O (1999) Çürüksu (Lycus) vadisindeki üç antik kent ve onların tarihsel su yapıları. In: Denizli'de sanayileșme ve kentleșme sempozyumu, Makina Mühendisleri Odası, Denizli, pp 117-127

Baykan O, Cantilav T (1997) Cibyratis birliği tarihsel su iletimleri (Cibyra, Oenoanda, Bubon, Balbura). In: Türkiye İnşaat Mühendisliği 14.Teknik Kongresi, İnşaat Mühendisleri Odası, İzmir, pp 1099-1114

Baykan O, İșkan H (2011) Patara eskil kenti su iletim ve dağıtım sistemi. In: 2.Su Yapıları Sempozyumu, İnșaat Mühendisleri Odası, Diyarbakır, pp 67-78

Baykan O, Tanriöver E (2006) Water supply system of the ancient city Tralleis. In: Wiplinger G (ed) Cura Aquarum in Ephesus 2004. Österreichisches Archäologisches Institut, Wien, pp 133-136

Baykan O, Kocakaya İ, Alkaya D (1997) Patara tarihsel su iletimi. In: Türkiye İnşaat Mühendisliği 14.Teknik Kongresi, İnşaat Mühendisleri Odası, İzmir, pp 1067-1082

Baykan O, Tanrı̈ver E, Çiftçi İ (2001) Historical water supply system of Magnesia on the Meander. In: International Symposium on water resources and environmental impact assessment, Istanbul Water and Sewerage Authority, İstanbul

Baykan O, Alkan A, Bacanlı Ü, Baykan N, Öziș Ü (2011) Testing flood estimation methods on ancient closed conduits. In: International Balkans Conference on Challenges of Civil Engineering, EPOKA University, Tirana, pp 1-8

Belli O (1996) Doğu Anadolu Bölgesinde keşfedilen Urartu barajlarına toplu bir bakıș. Belleten 229:638-751

Belli O (1997) Doğu Anadolu'da Urartu sulama kanalları-Urartian irrigation canals in eastern Anatolia. Arkeoloji ve Sanat, İstanbul

Bildirici M (1994) Tarihi Su Yapıları: Konya, Karaman, Niğde, Aksaray, Yalvaç, Side, Mut, Silifke. Devlet Su İşleri, Ankara

Bildirici M (2002) The water supply system of ancient Galata in Istanbul. In: 18th Congress, History Seminar, International Commission on Irrigation and Drainage, Montreal, pp 1-11

Bildirici M (2004) Tarihi sulama, su depolama, taşkın koruma tesisleri. Devlet Su İșleri, Ankara

Bildirici M (2006) The cistern and aqueduct of Keramos in Ancient Caria. In: Wiplinger G (ed) Cura Aquarum in Ephesus 2004. Österreichisches Archäologisches Institut, Wien, pp 147-150

Bildirici M (2008) Kilyos water supply system with suterazis. In: Ohlig C (ed) Cura Aquarum in Jordanien, 2007. Deutsche Wasserhistorische Gesellschaft, Siegburg, pp 341-343

Bildirici M (2014) Karaman Ermenek Yukarı Çağlar-water tunnels and water supply system of ancient Sbede. In: Ohlig C, Tsuk T (eds) Cura Aquarum in Israel II, 2012. Deutsche Wasserhistorische Gesellschaft, Siegburg, pp 275-284

Bildirici M, Bildirici Ö (1996) Historical irrigation in the plain of Ereğli of Konya. In: 16. International Congress, History Seminar, International Commission on Irrigation and Drainage, Cairo, pp 179-194

Burdy J, Lebouteiller P (1998) L'acqueduc romain de Xanthos. Anatolia Antiq Eski Anadolu 6:227-248

Burdy J, Taşlialan M (1997) L'acqueduc d'Antioche de Pisidie. Anatolia Antiq Eski Anadolu 5:133-166

Burney C (1972) Urartian irrigation works. Anatol Stud 22:179-186

Büyükkolancı M, Şimșek C (2006) Die Aquädukte und das Wasserverteilungssystem von Laodikeia ad Lycum. In: Wiplinger G (ed) Cura Aquarum in Ephesus 2004. Österreichisches Archäologisches Institut, Wien, pp $137-146$

Büyükyıldırım G (1994) Antalya bölgesi tarihi su yapıları. Devlet Su İsleri, Ankara

Çeçen K (1979a) A great hydraulic engineer at the XII. Century: Al-Jazari. In: XVIII. Congress, International Association for Hydraulic Research, Cagliari, pp 690-693

Çeçen K (1979b) Osmanische Wasserbauten in İstanbul. In: Leichtweiss-Institut für Wasserbau, Mitteilungen 64, Technische Universität, Braunschweig, pp 1-21 
Çeçen K (1981) Osmanlılar devrinde Karadeniz-Sakarya-İzmit bağlantısı. In: I.Uluslararası Türk-İslam Bilim ve Teknoloji Tarihi Kongresi, İstanbul Teknik Üniversitesi, İstanbul, pp 5/225-248

Çeçen K (1987) Seldschukische und osmanische Talsperren. In: Garbrecht G (ed) Historische Talsperren. Wittwer, Stuttgart, pp 275-295

Çeçen K (1988) Mimar Sinan ve Kırkçeșme Tesisleri. İstanbul Su ve Kanalizasyon İdaresi, İstanbul

Çeçen K (1990) Sinan's water supply system in İstanbul. İstanbul Su ve Kanalizasyon İdaresi, İstanbul

Çeçen K (1991a) Halkalı Suları. İstanbul Su ve Kanalizasyon İdaresi, İstanbul

Çeçen K (1991b) Üsküdar Suları. İstanbul Su ve Kanalizasyon İdaresi, İstanbul

Çeçen K (1992) Taksim ve Hamidiye suları. İstanbul Su ve Kanalizasyon İdaresi, İstanbul

Çeçen K (1996) The longest roman water supply line. Türkiye Sınai Kalkınma Bankası, İstanbul

Cezeri E (1196) Kitab-1 hiyel. Topkapı Sarayı Arșivi, İstanbul \& (Facsimile 1990) İsmâ'il ibn al-Razzâz Jazarî, Olağanüstü mekanik araçların bilgisi hakkında kitap. Kültür Bakanlığı, Ankara

Çınaroğlu, A (2007) Alaca Höyük Hitit barajı onarımı. In: Tarihi eserlerin güçlendirilmesi ve geleceğe güvenle devredilmesi sempozyumu-1, İnşaat Mühendisleri Odası, Ankara, pp 105-107

Commito AR, Rojas F (2010) The aqueducts of Aphrodisias. In: Ratté C, Staebler PD (eds) The Aphrodisias regional survey 5. Mainz, Zabern, pp 289-307

Coulton JJ (1987) Roman aqueducts in Asia Minor. In: Macready S, Thompson FH (eds) Roman architecture in the Greek world. The Society of Antiquaries, London, pp 72-84

Crouch DP (2004) Geology and settlement: Greco-Roman patterns. Oxford, New-York

D.S.İ (2008) Tarihi su yapıları konferansı. Devlet Su İșleri II. Bölge Müdürlüğü, İzmir

Dinçkal N (2001) Die'Compagnie des eaux de Scutari et Kadi-keui' und die Versorgung der asiatischen Seite Istanbuls durch das Wasserwerk Elmalı (1888-1904). In: Dinçkal N, Mohajeri M (eds) Blickwechsel 2000. Technische Universität, Berlin, pp 117-137

Dinçkal N (2005) Istanbul und das Wasser-Zur Geschichte der Wasserversorgung und Abwasserentsorgung von der Mitte des 19.Jahrhunderts bis 1966. Oldenbourg, München

Döring M (2012) Die antiken Wasserbauten von Antiochia, Türkei. Wasserwirtschaft 1-2:10-16

Emre K (1993) The Hittite dam of Karakuyu. In: Prince HM, Masaka T (ed) Essays on anatolian archeology, Wiesbaden, pp 1-42

Eyice S (1979) Byzantinische Wasserversorgungsanlagen in İstanbul. In: Leichtweiss-Institut für Wasserbauten, Mitteilungen, 64, Technische Universität, Braunschweig, pp 1-31

Fahlbusch H (1987a) Elemente griechischer und römischer Wasserversorgunsanlagen. In: Die Wasserversorgung antiker Städte 2, Zabern, Mainz, pp 133-163

Fahlbusch H (1987b) Die Wasserversorgung des hellenistischen Pergamon. In: Leichtweiss-Institut für Wasserbau, Mitteilungen, 97, Technische Universität, Braunschweig, pp 65-98

Fahlbusch H (1987c) Beispiele antiker Wasserversorgungsanlagen: Aspendos. In: Die Wasserversorgung antiker Städte 2, Zabern, Mainz, pp 172-175

Fahlbusch H (1987d) Beispiele antiker Wasserversorgungsanlagen: Perge. In: Die Wasserversorgung antiker Städte 2, Zabern, Mainz, pp 193-195

Garbrecht G (1975) Bewässerungswirtschaft in der Geschichte: Urartu, 900-600 v. Chr. Zeitschrift für Bewässerungswirtschaft 1:63-74

Garbrecht G (1985) Wasser - Vorrat, Bedarf und Nutzung in Geschichte und Gegenwart. Rohwolt, Hamburg

Garbrecht G (ed) (1987a) Historische Talsperren 1. Wittwer, Stuttgart

Garbrecht G (1987b) Die Wasserversorgung des antiken Pergamon. In: Die Wasserversorgung antiker Städte 2, Zabern, Mainz, pp 11-48

Garbrecht G (ed) (1991a) Historische Talsperren 2. Wittwer, Stuttgart

Garbrecht G (1991b) Talsperre und Tunnel am Hafen Seleukeia. In: Garbrecht G (ed) Historische Talsperren 2. Wittwer, Stuttgart, pp 83-89

Garbrecht G (1991c) Vier antike Talsperren in Anatolien. In: Garbrecht G (ed) Historische Talsperren 2. Wittwer, Stuttgart, pp 91-100

Garbrecht G (1991d) Das Alter der Talsperre 'Faruk Bendi’ in Ost-Anatolien. In: Garbrecht G (ed) Historische Talsperren 2. Wittwer, Stuttgart, pp 277-280,

293-294

Garbrecht G (1995) Meisterwerke antiker Hydrotechnik. Teubner, Stuttgart

Genç S, Baykan O, Baykan N, Bacanlı Ü (2010) Bezirgan (eskil Pirha kenti) kapalı havzası eskil tüneli akaçlama olayı. In: VI.Ulusal Hidroloji Kongresi, Pamukkale Üniversitesi, Denizli, pp 77-87

Gerger R, Kürkçüoğlu K (1997) Şanlıurfa'daki tarihi su yapıları. In: Türkiye İnşaat Mühendisliği 14.Teknik Kongresi, İnşaat Mühendisleri Odası, İzmir, pp 1129-1144

Grewe K (1994) Die römische Wasserleitung nach Side (Türkei). Antike Welt 2:192-203

Grewe K (1998) Licht am Ende des Tunnels: Planung und Trassierung im antiken Tunnelbau. Zabern, Mainz

Grewe K (2010) Meisterwerke antiker Technik. Zabern, Mainz 
Grewe K, Kessener P (2007) A stone relief of a water-powered stone saw at Hierapolis. In: Énergie hydraulique et machines élévatrices d'eau dans l'antiquité, Napoli, 227-234

Grewe K, Öziș Ü, Baykan O, Atalay A (1994) Die antiken Flussüberbauungen von Pergamon und Nysa (Türkei). Antike Welt 4:348-352

Grewe K, Öziș Ü, Alkan A (2010) Umleitung mitten durch den Fels (Der Titus-Tunnel bei Çevlik). Antike Welt 6:56-62

Hill R (1974) The book of knowledge of ingenious mechanical devices. Reidel, Dordrecht

Hodge T (1992) Roman aqueducts and water supply. Duckworth, London

I.W.A. (2012) 3rd IWA Specialized Conference on Water and Wastewater Technologies in Ancient Civilizations. International Water Association, İstanbul

İnal İ (2009) Hittite dam from 1250 BC towards today - MÖ 1250'den günümüze Hitit baraj1. Devlet Su İşleri, Ankara

İșkan H, Baykan NO (2013) Neue Ergebnisse zur Wasserleitung von Patara/Türkei. In: Wiplinger G (ed) Historische Wasserleitungen 2011 Frontinus-Gesellschaft, Berlin, pp 93-103

İzmirligil Ü (1979) Die Wasserversorgunsanlagen von Side. In: Leichtweiss-Institut für Wasserbau, Mitteilungen 64, Technische Universität, Braunschweig, pp 1-25

İzmirligil Ü (1983) Samsat (Samosata) su yolu araștırması, 1981. In: IV Kazı Sonuçları Toplantısı 1982, Kültür ve Turizm Bakanlığı, Ankara, pp 345-356

Kayan I (2000) The water supply of Troia. Stud Troica 10:135-144

Kessener P (2001) The Aspendos Aqueduct, an outstanding example of Roman hydraulic technology. FrontinusGesellschaft-Hefter 24:95-108

Kessener P, Piras S (1997) The pressure line of the Aspendos aqueduct. Adalya II:159-187

Kreiner R (2013) Die Mühlen des Değirmendere Aquäduktes von Ephesos und des Aquäduktes von Anaia/ Kadıkalesi (Türkei). In: Wiplinger G (ed) Historische Wasserleitungen 2011. Frontinus-Gesellschaft, Berlin, pp 131-138

Martens F (2006) The diachronic research of urban water management at Sagalassos, Southwest-Turkey. In: Wiplinger G (ed) Cura Aquarum in Ephesus 2004. Österreichisches Archäologisches Institut, Wien, pp 165171

Mays LW (ed) (2010) Ancient water technologies. Springer, Dordrecht

Murphy D (2006) The cisterns and reservoirs of Rhodiapolis, Southwest-Turkey. In: Wiplinger G (ed) Cura Aquarum in Ephesus 2004. Österreichisches Archäologisches Institut, Wien, pp 159-164

Murphy D (2013) The aqueduct of Elaiussa Sebaste in rough Cilicia. In: Wiplinger G (ed) Historische Wasserleitungen 2011. Frontinus-Gesellschaft, Berlin, pp 71-84

Neve P (1969/70) Eine hethitische Quellgrotte in Boğazköy. Istanbuler Mitt 19/20:97-107

Nikolic M (2008) Cross disciplinary investigation of ancient long-distance water pipelines. Dissertation, University of Victoria

Ögün B (1970) Van'da Urartu sulama tesisleri ve Șamram (Semiramis) kanalı. Anadolu, Ankara

Ortloff CR, Crouch DP (1998) Hydraulic analysis of a self-cleaning drainage outlet at the Hellenistic city of Priene. J Archeol Sci 25:1211-1220

Ortloff CR, Crouch DP (2001) The urban water supply and distribution system of the ionian city Ephesos in the roman imperial period. J Archeol Sci 28:843-860

Ortloff CR, Kassinos A (2003) Computational fluid dynamics investigation of the hydraulic behavior of the Roman inverted siphon system in Aspendos, Turkey. J Archaeol Sci 30:417-428

Owens E (2006) The aqueduct of Ariassos and the development of the Roman city. In: Wiplinger G (ed) Cura Aquarum in Ephesus 2004. Osterreichisches Archäologisches Institut, Wien, pp 151-157

Öziș Ü (1977) The ancient dams of İstanbul. Int Water Power Dam Constr 7:49-51, 8:44-47

Öziș Ü (1981) The ancient İstanbul dams within the perspective of dam technology history. In: I.International Congress on the History of Turkish-Islamic Science and Technology, İstanbul Teknik Üniversitesi, İstanbul, pp 3/19-30

Öziș Ü (1982) An outlook on ancient cisterns in Anatolia. In: International Conference on Rain Water Cistern Systems, University of Hawaii, Honolulu, pp 9-15

Öziș Ü (1984) Historische Staumauern und Fernwasserleitungen von İstanbul. Wasserwirtschaft 4:211-215

Öziș Ü (1987) Historical parallels in the water supply development of Roma and İstanbul. In: Wunderlich WO, Prins JE (eds) Water resources developments in perspective. Balkema, Rotterdam, pp 35-44

Öziș Ü (1991) Alabanda und seine antike Wasserversorgung. Antike Welt 2:106-113

Öziş Ü (1994) Su mühendisliği tarihi açısından Türkiyedeki eski su yapıları. Devlet Su İşleri, Ankara

Öziș Ü (1996) Historical water schemes in Turkey. Water Resour Dev 3:347-383

Öziș Ü (1998) Wasserbauten im Laufe von 4000 Jahren in der Türkei. In: Terzioğlu A, Bayazit M (eds) In Memoriam - Prof.Dr. Kazım Çeçen - Anma Kitabı - Gedenkschrift. Renk Ajans, İstanbul, pp 137-150 
Öziş Ü (1999) Historical dams in Turkey. Turkish National Committee of International Commission on Large Dams, Ankara

Öziș Ü (2001) Ein Einblick in die historischen Wasserversorgungsanlagen İstanbuls. In: Dinçkal N, Mohajeri S (eds) Blickwechsel 2000. Technische Universität, Berlin, pp 73-86

Öziş Ü (2006) Wasserbauten im Laufe von vier Jahrtausenden in der Türkei. In: Wiplinger G (ed) Cura Aquarum in Ephesus 2004. Osterreichisches Archäologisches Institut, Wien, pp 115-120

Öziș Ü, Arısoy Y (1986) Edirne water conveyance system constructed by the Great Mimar Sinan. In: II.International Congress on the History of Turkish- Islamic Science and Technology, İstanbul Teknik Üniversitesi, İstanbul, pp 2/135-144

Öziş Ü, Arısoy Y (1987) Mimar Sinan'ın Suyolları. Dokuz Eylül Üniversitesi, İzmir

Öziş Ü, Arısoy Y (1988) The water conveyance system of Edirne. Environ Des 7:68-73

Öziş Ü, Arısoy Y (1996) Water conveyance systems of the great Architect Sinan. In: Aktaş-Yasa A (ed) Uluslararası Mimar Sinan Sempozyumu 1988, Atatürk Kültür, Dil ve Tarih Yüksek Kurumu, Ankara, pp $241-256$

Öziş Ü, Arısoy Y (2000) Sinan's aqueducts. In: International Symposium: Bridging Large Spans (BLS) - From Antiquity to Present, International Association of Shell and Spatial Structures and Mimar Sinan University, İstanbul, pp 11-20

Öziş Ü, Arısoy Y (2003) Mühendis ve Mimar Sinan'ın suyolları. In: DOlen E, Kaçar M (eds) İhsanoğlu E (pres) Türk Teknoloji Tarihi 2001. Türk Bilim Tarihi Kurumu \& İstanbul Su ve Kanalizasyon İdaresi, İstanbul, pp $259-277$

Öziş Ü, Atalay A (1999) Fernwasserleitungen von Ephesos. In: Friesinger H, Krinzinger F (eds) Brandt B, Krierer K.R. (red) 100 Jahre Osterreichische Forschungen in Ephesos, Akten des Symposions Wien 1995, Osterreichische Akademie der Wissenschaften, Wien, pp 405-411

Öziş Ü, Atalay A, Haşal M, Atalay (Utku) V (1979a) Antike Fernwasserleitungen von Alabanda und Gerga. Leichtweis-Institut für Wasserbau, Mitteilungen 64, Technische Universität, Braunschweig, pp 1-8

Öziș Ü, Harmancioğlu N, Baykan O, Ünal İ, Tolkun M (1979b) Flood flows and capacities of the historical Pergamon and Nysa tunnels in Anatolia. In: XVIII.Congress, International Association for Hydraulic Research, Cagliari, pp.695-698

Öziș Ü, Atalay A, Becerik M, Özdikmen K (1998) Historical water conveyance systems to Ephesus. In: From Past to Present, Selçuk, First International Symposium 1997, Selçuk Municipality \& Ege University, Selçuk, pp 125-136

Öziş Ü, Özdemir Y, Kosova A, Çördük A (1999) İzmir'in tarihi su getirme sistemleri. In: İzmir Su Kongresi, Mühendislik ve Diğer Meslek Odaları İzmir Subeleri, İzmir, pp 45-56

Öziș Ü, Atalay A, Becerik M, Özdikmen K (2005) Tunnelstrecken in Qanatbauweise: der Kenchrios(Değirmendere)-Fernwassereitung nach Ephesus. Frontinus-Gesellschaft-Hefter 26:293-300

Öziş Ü, Arısoy Y, Alkan A, Özdemir Y (2007) Brücken und Wasserbauten aus seldschukischer und osmanischer Zeit in der Türkei. Spur, Zürich

Öziş Ü, Baykan O, Atalay A, Arısoy Y, Alkan A, Özdemir Y (2009) Water bridging civilizations through four millenia in Turkey. 5th World Water Forum - İstanbul, State Hydraulic Works, Ankara

Öziş Ü, Harmancıoğlu N, Alkan A (2010) Tarihi su tünelleri ve benzeri örtme yapılarının hidrolik kapasiteleri ve karșı gelen taşkınların dönegelim süreleri. In: Karahan H, Baykan NO (eds) VI.Ulusal Hidroloji Kongresi, Pamukkale Üniversitesi, Denizli, pp x-xxi

Öziş Ü, Atalay A, Özdemir Y (2014a) Hydraulic capacity of ancient water conveyance systems to Ephesus. Water Sci Technol Water Supply 6:1010-1017

Öziș Ü, Baykan O, Atalay A, Arısoy Y, Alkan A, Özdemir Y (2014b) Historische Wasserbauten in der Türkei. Wasserwirtschaft 7/8:83-86

Sarıkaya HZ, Eroğlu V, Altay A (2001) The history of sewerage services in İstanbul. In: Dinçkal N, Mohajeri S (eds) Blickwechsel 2000. Technische Universität, Berlin, pp 139-150

Schnitter N (1979) Antike Talsperren in Anatolien. Leichtweiss-Institut für Wasserbau, Mitteilungen 64. Technische Universität, Braunschweig, pp 1-8

Schnitter N (1990) Der Architekt Sinan als Wasserbauer. Wasser Energ Luft Eau Enérg Air 10:300-302

Schnitter N (1994) A history of dams. Balkema, Rotterdam

Seigne J, Morin T (2006) Water-powered stone saws in late antiquity. In: Wiplinger G (ed) Cura Aquarum in Ephesus 2004. Österreichisches Archäologisches Institut, Wien, pp 371-378

Stenton EC, Coulton JJ (1986) Oinoanda, the water supply and aqueduct. Anatol Stud 36:15-59

Strobel K (2013) Das Wassermanagement hethitischer und hellenistisch-römischer Zeit in Zentralasien. In: Wiplinger G (ed) Historische Wasserleitungen 2011. Frontinus-Gesellschaft, Berlin, pp 55-70

Tanriöver E, Baykan O, Baykan N (2006) The water supply systems of Caria —an inventory study. In: Wiplinger G (ed) Cura Aquarum in Ephesus 2004. Österreichisches Archäologisches Institut, Wien, pp 127-132

Tölle-Kastenbein R (1990) Antike Wasserkultur. Beck, München 
Tomasello F (1991) L'acquedotto romano e la necropoli presso l'istmo. Bretschneider, Roma

Türk S, Baykan O, Tanriöver E, Kaya B (2010) Likya bölgesi eskil su mühendisliği sistemleri. In: Karahan H, Baykan NO (eds) VI.Ulusal Hidroloji Kongresi. Pamukkale Üniversitesi, Denizli, pp 110-125

Tuttahs G (1998) Milet und das Wasser, ein Beispiel für die Wasserwirtschaft einer antiken Stadt. Universität GH Essen, Essen

Ünal M (2001) İzmit antik su sistemleri ve Pașasuyu. Kocaeli Dokümantasyon Merkezi, İzmit

Unutmaz İ (2013) Anadolu'da antik dönemden günümüze su mühendisliği harikalar. Wilo, İstanbul

Uytterhoeven I (2013) Aqueducts as suppliers of private water facilities in late roman Asia Minor. In: Wiplinger G (ed) Historische Wasserleitungen 2011. Frontinus-Gesellschaft, Berlin, pp 139-162

Viollet P-L (2000) L'hydraulique dans les civilisations anciennes. Ponts et Chaussées, Paris

Weber G (1899) Die Wasserleitungen von Smyrna I und II. In: Jahrbuch des Deutschen Archälogischen Instituts 14, Berlin, pp 14/4-25, 167-188 \& 29/95-96. \& (transl.: Pınar İ 2011) İzmir'in suyolları. İzmir Büyükșehir Belediyesi, İzmir

Wiplinger G (ed) (2006a) Cura Aquarum in Ephesus 2004, Österreichisches Archäologisches Institut. Wien \& Peeters, Leuven

Wiplinger G (2006b) Wasserlabyrinth unter Ephesos. Antike Welt 6:69-77

Wiplinger G (2010) Die Wasserversorgung von Ephesos in byzantinischer Zeit. In: Daim F, Drauschke J (eds) Byzanz, das Römerreich im Mittelalter. Roman-German Centralmuseum, Mainz, pp 593-613

Wiplinger G (ed) (2013a) Historische Wasserleitungen - Gestern - Heute - Morgen (Int. Frontinus-Symposium, Wien 2011). Frontinus-Gesellschaft, Berlin

Wiplinger G (2013b) Der Değirmendere Aquädukt von Ephesos und seine Zukunft. In: Wiplinger G (ed) Historische Wasserleitungen 2011. Frontinus-Gesellschaft, Berlin, pp 105-129

Wiplinger G (ed) (2014) International Congress on the history of water management and hydraulic engineering in the Mediterranean region-Programme and Abstracts. Frontinus-Gesellschaft \& Österreichisches Archäologisches Institut (Full-text proceedings will be published). Antalya 